\title{
Participatory Design as a Tool for Sustainable Regional Development
}

AUTHORS:

\section{Marián Ontkóc ${ }^{1 *}$ \\ Veronika Kotradyová ${ }^{2}$ \\ 1,2 Slovak University of Technology in Bratislava, Faculty of Architecture and Design, Institute of Interior and Exhibition Design, Slovakia}

\section{*CORRESPONDING AUTHOR}

E-mail: marian.ontkoc@stuba.sk

\section{ARTICLE INFO}

Sent: Apr 28, 2021

Accepted: Jun 11, 2021

\begin{abstract}
Globalization changes our world too quick and regions cannot keep up. Copying mechanisms affect crafted products and architecture and create specific signs for each region. Understanding that, we can follow cultural concepts and transform them to fit the current era and sustain local identity within communities. Compared with evolution, community attachment as part of social sustainability has the same self-regulated mechanisms. The adaptation process can be achieved in different ways, but only few are truly sustainable.

To restore the sense of community and reconnect local people to their village at a deeper level, the participatory approach was tested. The process and tools well known from urban areas were applied in certain Slovak villages. As compared to participation in cities, in the rural environment, the process is more time-consuming. In theory, this should bring a result that lasts longer than that achieved by standard processes.

Methods proposed by us will have several outcomes like networking, open communication and, if successful, can be an inspiration for other villages and activists to adopt the approach. This time-demanding activity can help to support local people and show them how to coordinate themselves in the decision-making process. The bottom-up approach increases self-esteem and by place-making, small public intervention can help with communication with local municipalities. In this process, the designer acts as a facilitator of a multidisciplinary innovation project and must use own creativity to handle many challenges.
\end{abstract}

KEYWORDS:

participatory design, social sustainability, rural, community, place attachment

\section{INTRODUCTION}

The goal of this activity is to empower the sense of community in rural areas in a selected region in Slovakia through the participatory design approach. This should increase communication between people and its self-government and trust. Attachment to a place has deep psychological urge to express ourselves in part of the group or part of a place by evolutionary point of view.

This paper was created as part of the IDENTITY SK project - the common platform of design, architecture and the social sciences in form of regional concepts for products and services from sources such as interdisciplinary literature, field research and storytelling

\section{IDENTITY}

In the theoretical part, this paper seeks to find out what the identity as a part of social sustainability means [1]. This term is broadly used in every field of science and in colloquial speech.
According to Podoba, identity is a social construct, which is evolving and changing through time, adapting to the current state of society [2]. For the needs of this paper, the meaning of identity used in sociology will be used. Identity (from the Latin identicus - identical, the same), otherwise also called 'authentic being', is a term denoting the unity of the inner psychological life of man and his actions. It is also an intense sense of self-identity that the individual experiences with his community [3]. Cultural identity is also a process in which a certain community identifies with cultural heritage of ancestors, protects and otherwise slows down its demise for reasons of preserving cultural continuity for future generations [4]. It is an essential tool for organizing human communities at the local, regional, state, or ethnic level. The loss of identity has always meant the decay of the community (gradual dissolution in a foreign cultural environment [5]. Identity is also abused by politicians to play for their benefit. It is mostly used emotionally in debates and speeches. For this reason, studying identity in this paper is based on the sense of belonging (to community and to space). 


\section{SENSE OF BELONGING, ATTACHMENT TO COMMUNITY}

A sense of belonging begins as an attachment to the caregiver. This critical need is the essence of surviving. We are deeply dependent on someone from the beginning and carry that hormonal attachment with us throughout our lives. Children who have not achieved a healthy connection in childhood may have many health problems (depression, lower self-esteem, weight issues...), are distrustful and may perceive rejection [6]. These conditions can lead to an individual's ability to connect with others and create a cycle of events that undermines a sense of belonging. Connection with caring individuals increases over time. The sense of belonging is also acceptance as a member or part of a group and extends into a sense of community. This feeling is related to levels of the oxytocin hormone $[7, \mathbf{8}, \mathbf{9}, \mathbf{1 0}]$. On the other hand, people can form attachments just because they live close to each other [11]. Our ability to survive in groups allows us to adapt to certain communities, to silence or develop our personality traits. We are shaped by the community and vice versa. The unspoken rules of the group that ensure the survival of the group as a whole can be defined as culture. If I follow these rules, the group has a better chance of survival and I, as a member, can survive as well. Over time, the rules become more abstract and begin to differentiate themselves from other groups. It has to do with competition for limited resources. Groups may compete for real or perceived scarcity of resources such as money, political power, military protection or social status. The same self-regulatory mechanisms within communities to sustain the group remain, but the content depends on the level of development [12]. The sense of belonging can also be interpreted as a reward system and as an oxytocin currency. Belonging is defined as a unique and subjective experience that relates to the desire for connection with others, the need for positive regard, and the desire for interpersonal connection [13]. A different view of culture and its relationship to genetics is held by the dual inheritance theory. According to this theory, culture is socially learned information stored in an individual's brain that is capable of influencing behaviour [14]. Cultural diffusion and evolution resemble genetic evolution through the process of adaptation. Cultural diffusion is a process through several copying mechanisms. Cultural patterns or formulae play a major role in this process. These are spread by cultural leaders (well-known members of the community) or new patterns copied by individuals in an effort to make them unique. All duplication of patterns is done unconsciously in most cases without knowing the origin of each aspect. As humanity becomes more interconnected, cultural patterns change faster than before. Regional specificities are slowly disappearing. Local people, surrounded by specific cultural patterns until recently, copy other international cultural patterns. Unique microregional traditions are not competitive with faster and cheaper ones. This leads to the perception that we need to preserve regional specificities and keep them in an untouchable "bubble" which, on the one hand, gives future generations a taste of the cultural background but, on the other hand, also protects it from natural evolution and adaptation.

\section{SENSE OF SPACE, ATTACHMENT TO PLACE}

If we look at the energy consumption of the brain, most of the energy is used to process new information. With more automatic and repetitive activity, less glucose is needed [15]. Attachment to a place can be described as something that is familiar, recognized, and the brain uses less energy to decode the space. Our mental projection of the universe is complete and we need to be "surprised" by the minimum. The brain can operate in a more automated "mode" and has less of a "fight or flight" response. Mental images of familiar places are perceived in both positive and negative connotations. This is the same as the concept of home in environmental psychology [16]. Place-based identity enhances the internal identity and integrity of the individual and the collective self. A sense of belonging is usually supported by a person's direct interaction with a place, but can also be mediated indirectly through social contacts. The context of a place will further influence a person's affinity for it. The availability of public services also induces positive feelings about a new place, whereas a large population has the opposite effect [17].

\section{PARTICIPATORY DESIGN}

Participatory design is currently the highest level of democracy in common decision-making. It is a communicative process prone to miscommunications like those in cross-cultural settings. While team members may belong to the same general culture, their varying occupational and social contexts are subcultures that bring different background assumptions, conventions of conversation, and semantics. Communicative failures may go undetected because mechanisms of conversational repair are among these differences. Team members may mistake failures in participatory behaviours for failure of participatory design. We identify conversational behaviours that reveal unshared assumptions among design team participants.

Participatory design must be more than having people present or even engaged in the process. This should be a dialogue among users on many levels. Participation is not a one-time act, such as calling a public meeting where people vote on what they want and do not want in the neighbourhood, but much more complex and a more sophisticated approach aimed at enabling meaningful public involvement in planning and decision-making processes. If the local self-government is the initiator of the process, it has a legitimate right to decide to what level public participation will be opened. It may be when, for example, the will to implement politics in a fully democratic way gives people (especially those pursuing their interests, which are paradoxically contrary to democratic principles) a chance to be heard. It should do so transparently and justify decisions.

Participation is a demanding process. Local people, even activists, who never experience a similar case and never think about public places that way, can be exhausted if the process is taking too long. Keep all sessions up to 2 hours, even if the work is going well. No session must have an open end. Everyone in the session must know what is going to happen next, have clear tasks and simple homework. [18]

Participatory design is used mainly in cities. Although participation is a more demanding and a long process, it has the potential to prevent possible future conflicts. It helps identify and accept the opinions and needs of various target groups: younger and older, women and men, boys and girls, motorists, fast or slow walking and non-walking, sports and non-sports based, individuals and families and therefore more sustainable [6]. The main 
difference between engaging local people into the process of decision-making between the urban environment and the countryside is that relationships are more intense in the countryside than in the cities and there is almost no anonymity. Self-control is on a higher level. People are more homogenous (age, cultural background, common history...). These differences must be taken into account. [19]

\section{DESIGNER AS FACILITATOR}

Designers are increasingly facilitating multidisciplinary projects. The participatory and user-cantered approach offers an opportunity to increase the generation of ideas, co-creation and transmit them more flexibly and openly. But we do not know how the designer as a facilitator influences these innovative projects. Designers as intermediaries contribute by identifying interactions between different levels of creative facilitation as a moderator for the level of implementation of cooperation. In this role, they must use their creativity to handle many other roles like organizing different steps, managing the group and spaces, introducing topics in an understandable way, setting up rules and culture for creative interaction, searching information and identifying categories, jointly identifying the problem and the evaluation criteria. During and the end of the whole process, they should provide critical design proposition, creative attitude and visual and 3D models. [20] From many experiences the hardest task for facilitators is to handle the dynamics within the group and also communicate the process and its result to the municipality or the public.

\section{METHODOLOGY AND RESEARCH STRUCTURE FOR THE CASE STUDY OF LOCAL DEVELOPMENT}

During the project entitled IDENTITA SK, the team has visited several regions in Slovakia (Honta, Gemer, Liptov, Orava...), analysed the potential and problems, had discussions with local activists and mayors or regional deputies. Eastern Slovakia was not part of these study trips. One of the authors comes from the Upper Zemplín region, knows the location and the people. As one of them, he had a better start and the trust of local people. For this reason, acquaintances that are involved in the development of the region on multiple levels were reached out to. According to their recommendations and further contacts, three potential villages were selected (Porúbka. Olšinkov, Modra nad Cirochou), but only in Porúbka was it possible to move a step further for now.

The bottom-up approach in local development was used to create a structure which is also tested for suitability in regional conditions. Each step can be evaluated and tested separately. This structure is conceived as open to different conditions in each region and village. It suggests different results fit local conditions and the current time. The whole structure will hopefully be tested in different regions. To put the hypothesis and experiences from urban environment into practice in rural areas, the region was selected by several parameters:

- villages with less than 500 inhabitants (without general plan),

- knowing active people with good contacts through whom I can gain trust of the local people,
- open local self-administration.

The Upper Zemplín region and counties: Humenné, Snina and Medzilaborce. Combining all parameters above, the village of Porúbka village was selected to be a pilot in testing the form of participatory design in rural areas. The will to change is the most important part of selecting a village or region to implement the participatory design in. Also crucial is a positive relationship between the municipality and local activists.

The first two steps have a goal to both analyse the potentials and raise awareness of local people about their region, to ask questions and find answers to identify the problems they are able to handle. The general plan represents basic information about the region, the potentials and the development. It is really good background and hard data for deeper analyses and a basis for future actions. Therefore, smaller villages usually do not possess those basic data about their own territory.

One of the results of the research will be the structure itself (Fig. 1). Each step can be assessed and tested and even if the community is not able to reach the result (for any reason), they can move forward with the partial outcome. Therefore, the process has the same value as the outcome. This structure was designed during conversations with local people willing to change something in the region. The process of creating together can support the sense of belonging and the result is adopted as their own. It can also improve local identity and have better maintenance in the future.

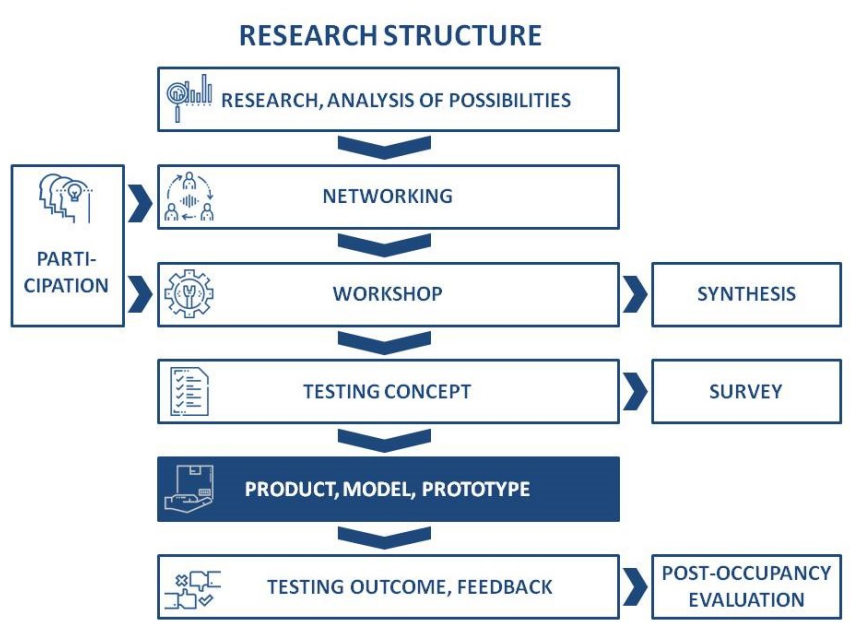

Figure 1: Scheme of research structure on the research study in regions, currently in Upper Zemplín. (C) Marián Ontkóc, 2019

\section{ANALYSIS OF UPPER ZEMPLÍN REGION}

Early settlements date back to the 14th century, as part of the colonization on Wallachian law, the mountainous areas of the region had been inhabited mainly by the Ruthenians. In the 18th century, there was a mass migration of the poorer sections of the population to the southern fertile regions and especially to the Lower Land for seasonal agricultural work and to work in America from the second half of the 19th century. From the national point of view, the population of Upper Zemplín consists of the 
Slovaks, Ruthenians-Ukrainians and the Roma. RutheniansUkrainians live mainly in the Low Beskydy Mountains up to the line of Stropkov, Papín, and Snina. Seven villages disappeared in the second half of the 1980s in connection with the construction of the Starina reservoir. Upper Zemplín is characterized by log houses, smeared and whitewashed with clay and lime. There is plenty of quarry stone in Vihorlat. [21]

The two world wars left a significant mark on the region. During the First World War, the main railway line through Humenné and Medzilaborce led to the Russian Front. Fighting also took place on the current Slovakia-Poland border and the battle lines lasted from November 1914 to May 1915. During this period, northeastern Slovakia gained great strategic importance and the Carpathian section of the Eastern Front became a place of intensive combat operations, which decided the further course of the First World War. The remnants of this operation are war and military cemeteries, mass graves and crypts [22]. At the end of the Second World War, partisan groups operated in the Vihorlat Mountains. After the suppressed Slovak National Uprising, several villages in the northeast of Slovakia were burned down (Chlmec, Porúbka, Tovarné, Tokajík...). Even before the battle of Dukla pass, the first village in the then Czechoslovakia - Kalinov - was liberated. Several bunkers in the forest have been preserved from this period, as well as monuments to remember both world wars, or local events. Natural highlights with greatest potential of tourist business are: Poloniny National Park with primeval forests, Unesco-protected forest in Vihorlat Mountains, wooden churches, darkest night-sky and medieval castles. Village involvement in those strong potentials with infrastructure and cultural influence is promising for local development.

\section{PORÚBKA}

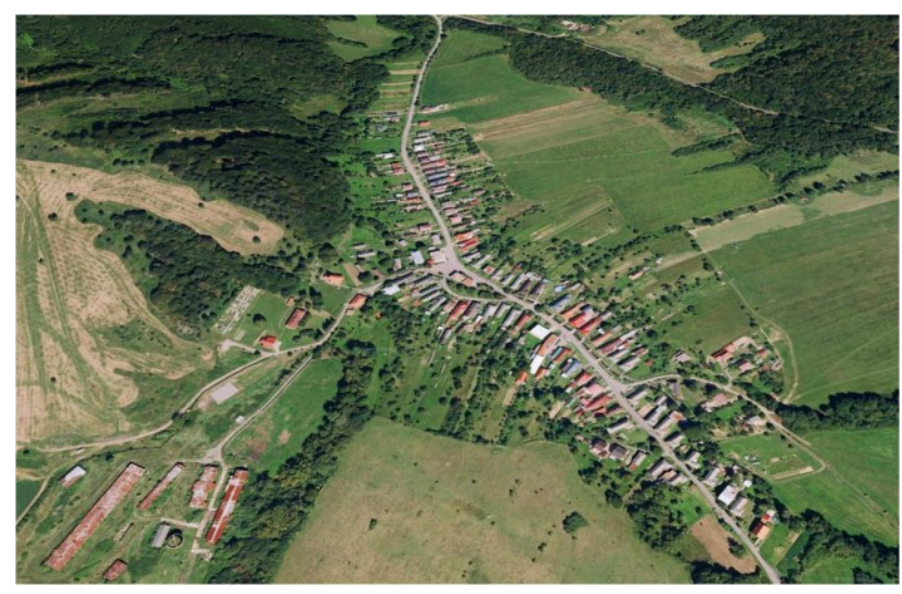

Figure 2: Porúbka village.

(C) www.mapy.cz, 2021

The village of Porúbka is located $11 \mathrm{~km}$ to the south of the district centre Humenné. It is located in the Vihorlat Mountains on the Ptava stream, at an altitude of $28 \mathrm{~m}$ above sea level. From the east side of the village, the border of the Valaškovce military district passes (Fig. 2), During World War II, in the nearby forests, there were partisan units and a field hospital. Therefore, Porúbka was burned down by the German soldiers and only 2 houses survived. During 1950s, the village was rebuilt using the same pro- ject of village house that was also used in other villages (Tovarné, Vit'azovce, Tokajík). The house plan has the shape of the letter $L$ and entrance from the yard, with 2 rooms facing the street. Some of them have a cellar beneath. Back in the yard is a farm with a stable and barn. It has hip roof with half-hip ending above the side room. The house was built with burned bricks and has asbestos cement roofing.

\section{FIELD RESEARCH}

After many minor meetings in various regions, the field research on the IDENTITA SK project in Upper Zemplín was progressing. First meetings were part of the first phase. That can help get to know local people or activists and prepare for later discussion with other groups. For now, there were two meetings. The first took place in Humenné, the second one in Porúbka (Fig. 3).

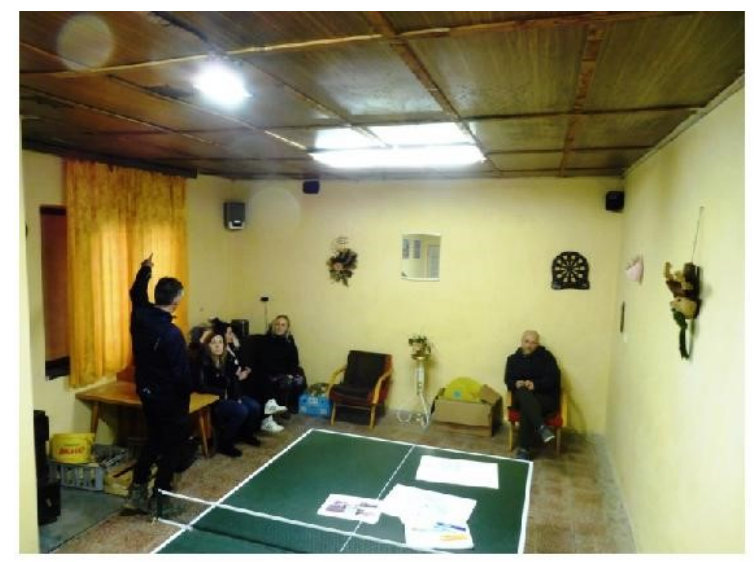

Porúbka

Involvement Age

Member of municipal council

Activist who moved in to the village

Local inhabitant of Porúbka

Local inhabitant of Porúbka

$50-60$

40-50

$50-60$

$30-40$

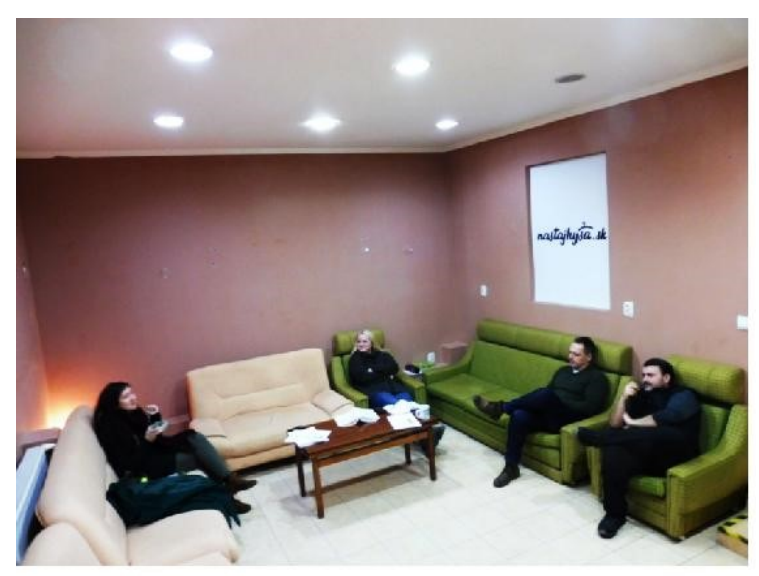

Humenné

Involvement Age

Former mayor of nearby village

50-60

Project manager for Poloniny

$30-40$

Local activist in Humenné

$30-40$

Local activist in Nechválová Polianka

$30-40$

Figure 3: Discussion with local activists in Upper Zemplín. (C) Marián Ontkóc, 2019 
This was only the first introductory meeting to recognise local needs and the way the research should continue. Currently, a questionnaire is taking place with questions to recognise potentials for improvement. The form was sent to several civic associations, local tourism businesses and official tourism agencies in selected counties. The results will be analysed in the final dissertation thesis. The information gathered during the first sessions can be divided into 3 categories (according to who and how can make changes) (Fig. 4):

\section{Capability of local people and mayors}

Local people do not know what they have in the region (cultural and natural heritage, history of village). Consequently, they are not able to identify values to be preserved and promoted. Young skilled people are moving to bigger cities or abroad to study or get a job. Very few come back and support local development. The mindset of those who stayed is, what we call, experienced by socialism. It depends on actions of higher authorities. Even if the community does not agree with some actions they obey, disagreement is not shown officially or at all. A combination of all of the above results in apathy (lethargy) of local people, usually expressed by gossips and those who stood against and are elected as mayor, become an authority but with the same mindset, unable to change much. There is also a strong competition among villages (regions) or even between parts of the same village (upper and lower part) etc. In some regions, this is very strong and has features of tribalism. A local solution is possible. Basic analysis can be performed using the tool of the local plan to find out the potential of each village and its possible uses. The relationship between the municipality and the "voters" is crucial. If there is lack of trust, the municipality can see similar activities as a threat. The minimum a local mayor or council can do is not to lock the door.

\section{Infrastructure}

Infrastructure represents technical issues. Missing roads or roads and pavements, sewage, fences in bad shape, old playgrounds, abandoned buildings, former cooperative areas, factories... The community needs more than local subsidies and must cooperate on a regional or state level to get funding for repairs.

\section{Legislation}

Villages are funded through state policy and receive money according to the size of population by calculi. As each month, a village gets a different amount of money, the municipal council does not know exactly how the amount is computed. There is space for corruption and constraint on mayors. Laws are not supportive of selling local products or creating a network of places to sell. Small villages with up to 500 inhabitants are not required to have a local plan. The community depends on a competent ministry and parliament (state level) to make any changes. In the next step, it is necessary to create a positive attitude with the local group.

The designer or architect is in the position of a mediator or facilitator. He or she must recognize potential through interviews and discussions and be able to direct common effort to the positive (sustainable) direction. This role requires more than creative abilities. On the other hand, it gives a better input to design than any other role.

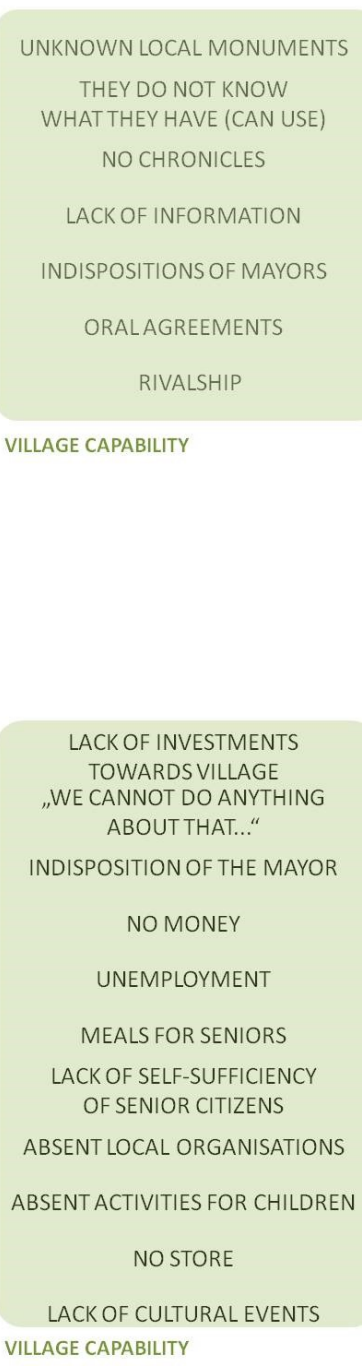

ROAD TO CEMETERY

IN BAD SHAPE

NO PATHWAYS ALONG THE ROAD

NO SEWERAGE

DILAPIDATED BUILDING OF THE KINDERGARTEN INFRASTRUCTURE

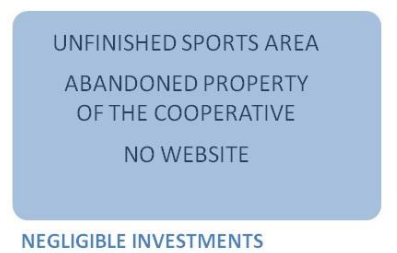

NEGLIGIBLE INVESTMENTS

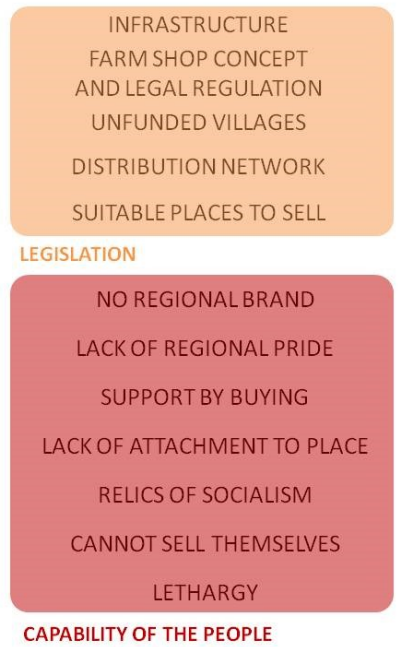

Figure 4: Clustered collected data from surveys,
split to 3 categories. (c) Marián Ontkóc, 2020

\section{ANALYSIS OF THE POTENTIAL OF THE PORÚBKA VIL- LAGE}

- close to the district centre $(11 \mathrm{~km})$,

- strong legacy of World War II (burning of the village, the work of partisans, a memorial, bunkers),

- stagnation of the village development and number of inhabitants for over 30 years,

- end village, access to the surrounded forests (primeval forest Kyjov, Vihorlat Mountains),

- undetected high attendance of tourists from the area (bicycle, car),

- land, building of a former kindergarten, pastures and orchards owned by the municipality, 
- closed pub and grocery store.

\section{PARTICIPATIVE METHODS}

There are many different methods of empowering people to be a part of the participative process, of process management and different tools for designers/facilitators such as mind maps, walking mapping, many types of surveys, public meetings, workshops etc. It is the responsibility of the designer or facilitator to choose the most suitable ones. Participation is best encouraged by methods such as guided discussion and group problem analysis and demonstrations prepared rather than external explanations or presentations. However, informal methods make much greater demands on designers than formal methods. In one form or another, discussion is an essential part of participative method of dealing with development. [23]

\section{LEVELS OF PARTICIPATION}

Clarification of expectations, identification of goals and desired outputs can help the authority decide how it will proceed. International Association for Public Involvement offers an overview of the levels of participation - from information and marking up to different levels of involvement and cooperation. When we involve the public, we start by informing. Participation will be successful if those who comment on the issues understand the topic and the reason for involvement. The second level is commenting (consultation). We speak about it when the public comments on already completed policies, studies or projects and makes observations that will need to be processed, assessed, accept or rejected. At this level, there is no space for fundamental changes to the proposals anymore, which may bring about frustration of the people involved.

Involvement and cooperation is a more challenging and deeper level of participation. The public no longer speaks out when the product is finished, but is engaged in this work from the beginning. The deeper the public involvement and share is in the creation of solutions, the more demanding is the process of facilitation (leading the public policy-making process). Some sources also indicate the latest level of participation - delegation or empowerment of citizens. This is a situation whereby the municipality (or the one vested with power) delegates the decision-making power to citizens. This approach is sometimes referred to as "civic" control. An example of such delegation can be local referendums or participatory processes budget. [24]

Participation means mutual trust between professionals, politicians and citizens, which can be transformed, for example, to better cooperation on projects. Participation springs from the community and the community retains ownership of the process. The purpose is to influence other sectors and strengthen the capacity of the community for the benefit of its own development.

\section{CONCLUSION}

The decision-making processes that go bottom up should lead to development of the creative potential of citizens, deeper accord, greater feeling of responsibility and mobilization of residents' own efforts in rural regions. Communication between citizens and local municipality is crucial to succeed to achieve a positive outcome. If one part is missing, the results remain theoretic only. The role of the designer is that of a facilitator.

The conclusion presented in the part entitled FIELD RESEARCH is a partial authors' summary of the notes from one of the meetings in the Humenné district, including several discussions in other regions within the framework of the IDENTITA SK project.

Short-time thinking, human potential and capability of local people are the main obstacles to sustainable inclusive development. Effective research by participatory design in rural areas can only be performed in person. Unfortunately, the current pandemic situation does not allow for a proper field research and completion and testing of the hypothesis yet. Time-consuming sessions, closed local archives (the only source of information about small villages) and intense human relationships have made us unable to continue the research. Research, local contacts network and local activities are still ongoing.

\section{REFERENCES:}

[1] Hawkes, J. (2001) "The fourth pillar of sustainability - Culture's essential role in public planning”. Common Ground Publishing, network, Victoria, England.

[2] Podoba, J. (2018) "Invented Tradition: Kontinuita a identita v podmienkach spoločnosti neskorej modernity", In: Zborník z medziodborovej dvojkonferencie Identita SK a INSK. Bratislava, Spektrum STU, Slovakia.

[3] Jandourek, J. (2001) "Sociologický slovník". Portál Praha, Czech Republic, pp. 106.

[4] Gregorová, J., Špaček, R. (2010) "Kultúrna udržatel'nost' ako podmienka kultivovanej obývatel'nosti mesta”, In: Solárne mestá. FA STU. Bratislava, Slovakia.

[5] Gažová, V. (1997) "Aktuálnost' problematiky identity v súčasnej kulturologickej reflexii”, In: Otázky žurnalistiky. Volume 40, Issue 1, pp. 13-18.

[6] Rubin, K. H., Coplan, R. J., Bowker, J. C. (2009) "Social Withdrawal in Childhood", Annual Review of Psychology, volume (60), pp. 141-171 https://doi.org/10.1146/annurev.psych.60.110707.163642 [DOI]. Available at: https://www.ncbi.nlm.nih.gov/pmc/articles/PMC3800115/ [7] Bales, K. L., van Westerhuyzen, J. A., Lewis-Reese, A. D., Grotte, N. D. (2007) „Oxytocin has dose-dependent developmental effects on pair-bonding and alloparental care in female prairie voles", Hormones and Behavior, Volume (52), issue 2, pp. 274-279. https://doi.org/10.1016/j.yhbeh.2007.05.004 [DOI] [8] Taylor, S. E., Gonzaga,G. C., Klein, L. C., Hu, P., Greendale, G. A., Seeman, T. E. (2006) "Relation of Oxytocin to Psychological Stress Responses and Hypothalamic-PituitaryAdrenocortical Axis Activity in Older Women", Psychosomatic Medicine, Volume (68), pp. 238-245.

https://doi.org/10.1097/01.psy.0000203242.95990.74 [DOI] [9] Taylor, S. E., Welch, W. T., Kim, H. S., Sherman, D. K. (2007) „Cultural Differences in the Impact of Social Support on Psychological and Biological Stress Responses“, Psychological Science, Volume (18) issue: 9 , pp. 831-837.

https://doi.org/10.1111/j.1467-9280.2007.01987.x [DOI] [10] Weller, A, Feldman, R., Zagoory-Sharon, O. (2007) "Evidence for a Neuroendocrinological Foundation of Human Affiliation: Plasma Oxytocin Levels Across Pregnancy and the Postpartum Period Predict Mother-Infant Bonding", Psychological Science, Volume (18), issue 11, pp. 965-970.

https://doi.org/10.1111/j.1467-9280.2007.02010.x [DOI] 
[11] Rogers, C. R. (1951) „Client-Centered Therapy; Its Current Practice, Implications, and Theory“, Houghton Mifflin, England.

[12] Jackson, J. W. (1993) "Realistic Group Conflict Theory: A Review and Evaluation of the Theoretical and Empirical Literature", Psychological Record, Volume (43) issue 3, pp. 395415.

[13] Baumeister, R., Campbell, J. D., Krueger, J., Vohs, K. (2003) "Does high self-esteem cause better performance, interpersonal success, happiness, or healthier lifestyles?”, Psychological Science, Volume (4), pp. 1-44.

[14] Richerson, P., Boyd, R. (2005). "Not By Genes Alone: How Culture Transformed Human Evolution", University of Chicago Press, Chicago, USA.

[15] Mergenthaler, P., Lindauer, U., Dienel, G. A., Meisel, A. (2013) "Sugar for the Brain: The Role of Glucose in Physiological and Pathological Brain Function", Trends Neurosci, Volume (36), issue:10, pp. 587-597.

https://doi.org/10.1016/j.tins.2013.07.001 [DOI]

Available at: https://www.ncbi.nlm.nih.gov/pmc/articles/PMC3900881/

[16] Naništová, E. (2002) “Koncept miesta v environmentálnej psychológii” Fakulta humanistiky Trnavskej univerzity v Trnave, Trnava, Slovakia.

[17] Xu, H., Bo, Z., Ye, L. \& Desheng, X. (2019) „Belonging to a Place: An Analysis of the Perceptions of Rural-to-Urban Migrants in China", Geographical Review, Volume (110) issue 3, pp. 406-424. https://doi.org/10.1111/gere.12366 [DOI] [18] Bobbio, L. (2019) "Designing Effective Public Participation", Policy and Society, Volume (38), issue 1, pp. 41-57. https://doi.org/10.1080/14494035.2018.1511193 [DOI] Available at:

https://www.tandfonline.com/doi/full/10.1080/14494035.2018.15 11193

[19] Wates, N. (2000) "The Community Planning Handbook", Earthscan Publications, London, UK.

[20] Bettin, M., Lassen, A. H. (2019) „The Designer as Facilitator of Multidisciplinary Innovation Projects", The Design Journal, Volume (21), issue 6, pp. 1-23.

https://doi.org/10.1080/14606925.2018.1527513 [DOI]

Avaliable at: https://www.researchgate.net/publication/330302976_The_Designer_as_Facilitator_of_Multidisciplinary_Innovation_Projects\#pfa

[21] Beňušková, Z., et al (2005) "Tradičná kultúra regiónov slovenska". VEDA, Bratislava, Slovakia.

[22] Drobňák, M., Korba, M., Turik, R. (2007) „Cintoríny prvej svetovej vojny v Karpatoch“. Redos, Humenné, Slovakia. [23] Newmann, H., Sidney, D. M. (1955) "Teaching Management: A practical handbook with special reference to the case study method ", pp .74-94, Routledge, London, England. https://doi.org/10.4324/9781351056342 [DOI] [24] Pauliniová, Z. (2018) "Občianske mesto a efektívna participácia”, IŠUP, Banská Bystrica, Slovakia. 